\title{
Orbánistan. Rädsla och avsky i det illiberala Ungern
}

Joakim Medin

Stockholm: Verbal förlag 2018

220 sider. ISBN 9789187777370

Omtalt av Eva Sarfi [universitetslektor, Sentral-Europa og Balkan-studier, Universitetet i Oslo, eva.sarfi@ilos.uio.no]

Den svenske journalisten Joakim Medin har skrevet en grundig og informativ bok om dagens politiske system i Ungarn. Boken er blitt til på grunnlag av et omfattende og balansert kildeomfang, og stoffet presenteres på en klar og for leseren lett tilgjengelig måte. Boken anbefales sterkt til alle med interesse for hva som skjer $\mathrm{i}$ ungarsk politikk i dag.

Medin redegjør for hvordan partiet Fidesz oppsto på 1980-tallet blant en liten krets universitetsstudenter der Viktor Orbán raskt markerte seg som en lederskikkelse. Den samme gruppen utgjør i dag kjernen i partiet og innehar alle sentrale politiske verv. Forfatteren viser også hvordan Fidesz utviklet seg fra å være et liberalt parti til å vektlegge en nasjonalkonservativ ideologi fra midten av 1990-tallet. Leseren får kjennskap til Orbáns bakgrunn og oppvekst i en fattig landsby preget av tradisjonelle verdier og tiltro til at en "landsfader» skal lede og beskytte fedrelandet. Orbán spiller på disse verdiene og fremstiller seg selv som landets far og beskytter. Medin viser hvordan myndighetene gjennom minnepolitikk forsterker den paternalistiske tradisjonen: Mellomkrigstidens politikk og lederen Miklós Horthy får stadig større plass i historiebøkene og i det offentlige rom, til tross for sterke antisemittiske innslag $\mathrm{i}$ ungarsk politikk den gang.

Et annet tema i boken er bølgen av flykninger som kom til Ungarn i 2015 og ungarske myndigheters valg om å bygge en grensemur for å stanse flyktningstrømmen. Boken får godt fram hvordan Orbán utnyttet denne krisen til å skape et nytt fiendebilde: de muslimske terroristene. Orbán klarte å snu en dalende popularitetstrend til egen fordel ved å formidle et budskap om at Fidesz alene er i stand til å beskytte fedrelandet mot muslimene som vil islamisere Ungarn og Europa.

Etter at flyktningstrømmen ebbet ut, var det avgiørende for Orbán å fastholde fortellingen om en ytre fiende og trussel. Valget falt på den ungarskfødte amerikanske finansmannen George Soros, som sponser en rekke menneskerettighetsorganisasjoner og organisasjoner som støtter demokratibygging i tidligere diktaturer. Ifølge 
Orbán har Soros en hemmelig agenda som går ut på å oversvømme Europa med muslimske innvandrere for å skape et kaos som muliggiør at finanskapitalen overtar all makt. Alle organisasjonene som får støtte fra Soros-fondene, framstilles som hans medsammensvorne i den hemmelige planen. Kampen mot Soros-nettverket er den viktigste begrunnelsen for at Orbán-regjeringen har vedtatt lover som har umuliggjort det for Central European University å bli værende i Budapest og innført ekstrabeskatning for utenlandsk-støttede frivillige organisasjoner. Medin viser at verken EU eller opposisjonspartiene har klart å forhindre vedtaket av disse lovene.

Kapitlene som tematiserer Orbáns vei til makten og hvordan Orbán og hans nærmeste krets har klart å omforme rettssystemet og anbudsordningene til egen fordel, er især klargjørende. Forfatteren setter de mange opplysningene om maktmisbruk og korrupsjon, som daglig presenteres i mediene og er velkjente for mange, $i$ en større sammenheng, og viser det overordnede bildet av hvordan korrupsjonen i Ungarn er satt i system. Leseren får innsikt i hvordan Orbáns barndomsvenn, den tidligere beskjedne rørleggeren Lörinc Mészáros, i løpet av få år er blitt Ungarns rikeste mann og borgermester i Orbáns fødelandsby Felcsút. Mészáros og andre Orbán-nære oligarker har bygget opp et omfattende finansimperium som kontrollerer store deler av ungarsk næringsliv. Mészáros fikk naturlig nok kontrakten for å bygge et stort fotballstadion i Felcsút, en landsby med under 2000 innbyggere, der Orbán har sitt landsted. Fotball er Orbáns favorittidrett, og i hele Ungarn foregår det i dag omfattende utbygging av fotballarenaer i Orbán-oligarkiets regi. Flesteparten av arenaene er ikke økonomisk bærekraftige. En annen oligark, Orbáns svigersønn István Tiborcz, kontrollerer de fleste utviklingsprosjektene rundt Balatonsjøen. Så å si alle store investeringsprosjekter i landet er i Orbán-oligarkiets hender.

Særdeles god er også delen som viser hvordan de fleste av de ungarske massemediene har havnet under regimets kontroll og tidvis bevisst skaper og sprer falske nyheter. Orbán bruker en stor del av de offentlige midlene til omfattende propagandakampanjer. Medin formidler godt den uhyggelige stemningen som hersker når gigantiske gateplakater, avisannonser og hyppige TV-reklamer viser en ondskapsfullt smilende Georg Soros eller opposisjonspolitikere arm i arm med Soros, plakater som sier «Stopp Brussel» eller «Stopp migrantene». Mange ungarere er klar over at budskapene som formidles har begrenset sannhetsgehalt, men når omfanget av propaganda og falske nyheter er så stort som det er, blir det vanskelig å skille mellom sant og usant og lett å henfalle i generell apati.

Forfatteren går flere steder i boken inn på grunnlaget for Orbáns ideologi og samfunnssyn. Han viser til en viktig forskjell mellom Orbán og de medlemmene av Fidesz som snudde ryggen til partiet i kjølvannet av den ideologiske høyredreiningen på 1990-talltet: Orbán kommer fra den ungarske landsbygda, mens de som meldte seg ut av Fidesz kommer fra urbane strøk og/eller familier med høy utdanning. Her viser Medin til kjernen i splittelsen i det ungarske samfunnet, som han med fordel kunne ha utdypet: Den ungarske nasjonalismen har røtter i landaristokratiet som mobiliserte mot habsburgerne for å bevare egne privilegier. Den nasjonale ideologi, som 


\section{EVA SARFI}

ble spredt til lavere befolkningslag, fokuserte på fortellinger om ungarsk storhetstid, nasjonale lederskikkelser og ytre fiender, og underkommuniserte klasseforskjeller og samfunnets autoritære trekk. Ungarns aristokrati beholdt sine jordeiendommer og dominerte politikken helt til 1944. Aristokratistyret, ledet av Horthy, hentet sin legitimitet fra landsbygda der jordeierne hersket og de nasjonale mytene som kamuflerte og opprettholdt de sterke klasseskillene dominerte. I hovedstaden, derimot, fikk industrialiseringen og liberale ideer fotfeste, og det oppsto således en sterk økonomisk og ideologisk splittelse mellom Budapest og resten av landet. Denne splittelsen eksisterer fortsatt.

I følge Medin kan Orbáns popularitet forklares med at han gjenskaper tryggheten på landsbygda som eksisterte under kommuniststyret. Men forfatteren nevner ikke at det var det rurale Ungarn som var kommunismens verste fiende. Under kommunismen var det problematisk å dyrke den autoritære nasjonalismen som utgjorde befolkningens identitet; likevel klarte ikke kommunistene å eliminere de nasjonale narrativene. Orbán oppdaget raskt at et ungarsk politisk regime har størst sjanse for å bli sterkt hvis det får med seg den nasjonalt orienterte befolkningen utenfor Budapest som utgjør befolkningsflertallet. Orbáns retorikk appellerer først og fremst til denne delen av det splittede Ungarn, noe som vises i de siste valgresultatene - Fidesz fikk $i k k e$ et flertall i hovedstaden.

Medin gir uttrykk for en frykt for at den ungarske modellen kan spre seg til andre europeiske land, Sverige inkludert. Men hvis det er riktig at Orbáns ideologi primært har gjennomslag fordi den opererer $i$ et land som inntil andre verdenskrig hadde dype føydale og autoritære trekk, er sannsynligheten for at systemet blir kopiert $\mathrm{i}$ andre land liten. 